\title{
Network Approach versus Brain Drain: Lessons from the Diaspora
}

\author{
Jean-Baptiste Meyer*
}

\begin{abstract}
For the past two decades, network approaches have led to many conceptual and empirical developments in the studies of international migration as well as of technological innovation. However, surprisingly, such approaches have hardly been used for the study of what is at the intersection of both fields, namely the mobility of highly skilled persons or knowledge workers.

This article draws on recent evidence brought by case studies on intellectual diaspora networks to bridge this gap and to explore the issue. These highly skilled expatriate networks, through a connectionist approach linking diaspora members with their countries of origin, turn the brain drain into a brain gain approach. These persons and groups also provide original information that questions conventional human capital based assumptions.

The article argues that descriptions in terms of network open interesting perspectives for the understanding as well as management of the current global skills' circulation. The network approach under consideration combines input from migration as well as from innovation studies. This suggests an expanded version of the network approach, referring to actors and intermediaries, of which traditional kinship ties are but a part of more systematic associative dynamics actually at work.
\end{abstract}

\section{INTRODUCTION}

The migration of knowledge workers has become a highly debated political issue relating to the globalization process as a result of the inexorable opening of national resources in a knowledge-based economy. It is often considered that

* Institut de Recherche pour le Développement, CEP - Université de Montpellier, France. 
human capital, like financial or physical capital, responds to market signals and wage differentials in a rational optimization of this factor. Inspired by endogenous growth theories which emphasize the role of knowledge in development processes, some economists have drawn attention to the inherent volatility of human capital, apparently confirmed by the increasing number of skilled emigrants (Haque and Kim, 1994; Carrington and Detragiache, 1998). However, this idea is based on a conception that human capital is in fact isolated: its accumulation corresponds basically to the education phase, which is assumed to be distinct from the rest of life and especially from professional time. Meanwhile, data on these skilled individuals are retrospective; their presence in a foreign country is counted as part of the brain drain, ignoring when and where their skills have been developed.

During the 1990s, many initiatives were taken on a pragmatic basis. Forty-one networks of highly skilled expatriates have been developed for the purpose of bringing these expatriates' individual and collective skills to 36 (developing) countries of origin (Brown, 2000). These initiatives, emanating from the diaspora as well as from the country of origin, take for granted that expatriates have left mainly because they did not have enough supportive networks (institutional, infrastructural, technical, educational, social, financial, etc.) to build, develop, express, use and to cash in on their skills at home. These expatriates are most likely to stay abroad because they are precisely inserted into such supportive networks, for and by which their skills have been created or channelled, and therefore have value in the relevant socio-economic context. This vision, which emphasizes potential gain instead of immeasurable loss, is based on a contextual, i.e. historical and social, view of skills and human resources. It may be considered as a paradigmatic shift from the earlier vision, since it is not completely comparable under the same terms.

This article explores and considers these conceptual changes in relation to earlier fertile developments in studies on migrant networks. It draws on innovation studies to make theoretical points from science- and technology-based networks. It then presents evidence brought by case studies on diaspora networks and other converging sources. Finally, certain theory as well as policy implications of these new elements are discussed.

\section{NETWORKS ANDLITERATUREON MIGRATION}

Network approaches have been used extensively across many disciplines during the last two decades, to such an extent that they have been credited as developing a new field referred to as network analysis (Gelderblom, 1999) or paradigm (Murdoch, 1995). Though the use of concepts related to these approaches takes care to avoid generality and vagueness, the heuristic and descriptive values of approaches of this kind have been asserted. This is especially the case for topics 
as varied as organization, information, innovation and migration where the notions of links and associations between various entities are encompassed by such approaches in terms of network. With regard to migration in particular, references to "migrant network" can be traced to Choldin (1973).

From the beginning, and with increasing precision, evidence and conceptual refinement, these networks have been presented as facilitating the migration process. Connections with earlier migrants provide potential migrants with many resources that they use to diminish the risks and costs of migration: information about procedures (technical as well as legal), financial support, job prospects, administrative assistance, physical attendance, emotional solidarity (Hammar et al., 1997).

Beside facilitation, the impact of social networks on migration flows is also one of channelling (Gelderblom, 1999), since immigrants naturally serve as bridgeheads for their fellow immigrants in both the geographical (countries) as well as the professional (occupation) areas in which they have settled (Banerjee, 1983; Boyd, 1989; Gurak and Caces, 1992). This type of channelling may sometimes become a form of limitation, selection and exclusion, limiting options for individuals outside those experimented by the group and facilitating moves to those connected at the expense of those deprived of equivalent social capital (Pohjola, 1991; Gelderblom, 1999).

The network approach has considerably enriched understanding of the migration process in various ways. Beyond macro-economic determinants of the supply and demand of manpower or the separate push and pull factors in different countries, it points to micro-meso-level dynamics as major explanatory factors of what is actually occurring. This approach has notably established a sociohistorical perspective, showing the weight of previous migratory events on the course of those occurring at a given time. It describes the shaping of migration systems linking particular countries in specific relationships through nexus developed as a result of continuous human inflows (Fawcett, 1989; Nogle, 1994).

A major success of the network approach in studies on international migration has been its contribution to a better understanding of the international labour market. Case studies on migrant networks have brought compelling evidence of the major effects of these networks on the transfer of manpower from one part of the world to another (Banerjee, 1983; Mullan, 1989; Gunnatilleke, 1998; Shah and Menon, 1999). These studies show the extent to which networks allow migrants to gain access to jobs in the recipient country. The forms and characteristics of these networks may depend on their composition - friends, relatives, kin, acquaintances, professional colleagues, etc. - but the result is similar: most positions are acquired via connections. This result is no different from what the sociology of networks as well as the economics of labour has clearly demonstrated, namely, that social relationships constitute the most 
effective means towards successful and mutually beneficial recruitments (Granovetter, 1974; Montgomery, 1991). The pre-existing relationship between the (future) employee and the employer, through the intermediary of an individual known by both, not only provides the employee with information about the job but also guarantees the employer that she/he is, to a certain extent, appropriate for the vacant post. Studies on migrant networks show that this powerful interplay is at work not only at the national level but also - and probably even more so, since institutional alternatives are less abundant - at the international level.

Highly skilled migration dynamics respond to the same logic, perhaps even further. Obviously, the recruitment of specialized staff requires some kind of bridge to facilitate adequate encounters between potential employers and employees. However, one very detailed case study on Hong Kong emigrants shows "a qualitative variation in the type of networks used by different occupational classes for migration purposes" (Wong and Salaaf, 1998: 358). According to this study, higher occupational groups tend to rely less on kin-based networks for accessing positions abroad than lower skilled individuals. They have more extensive and diverse networks consisting of colleagues, fellow alumni and relatives whom they can, and do, mobilize for their recruitments.

What case studies on migrant networks reveal without any doubt is the importance of connections - human mediation - in the migration process. This simple result unveils a different vision of this process, as being less the residual factor of a confrontation between supply and demand on the international labour market than the expression of global dynamics generated by human interactions. In providing the idea and opportunities of migration to individuals, networks in fact make them "migrants". As such, they are more than mere instruments. They are components and determinants of the migration process.

\section{THEHUMANCAPITALPARADIGM}

Surprisingly, the abundant literature available on the migration of highly skilled persons in particular - the so-called "brain drain" - almost never refers to networks. The most recent and complete bibliographical review of all publications on the topic during the last four decades includes only eight references about networking in a total of 1816 on the subject (Gaillard and Gaillard, 1998). Moreover, these few references do not deal with migration networks (networks through which people migrate) but rather with the integration of foreign students in host countries, the dynamics of the international scientific communities or new brain gain attempts through diaspora networks.

The main reason why the network approach has only exceptionally made its way to the higher skilled levels of the migrant population is that the study of these particular categories has mostly been dominated by a human capital paradigm. 
In fact, brain drain approaches are semantically and historically associated with the latter. The term "brain drain" officially appeared in 1963, a few months before the publication of Gary Becker's book set the theoretical bases of the human capital approach (Becker, 1964). Both refer to a substantialist view of skills as a stock of knowledge and/or abilities embedded in the individual. Naturally and literally, moving his/her body means moving the capital accumulated in it. During the following decades, this vision of human capital has generated very diverse, even sometimes opposite, approaches around the brain drain issue (the nationalist versus the internationalist point of view). It has indeed provided a strong and effective set of concepts, measures and empirical studies, in short, the heuristics and the exemplars, that the paradigm required in order to provide an effective framework of reference, according to Thomas Kuhn's definitions (Kuhn, 1962; Meyer and Charum, 1995). The paradigm, however, has failed in bringing operational solutions to the very political issue it directly addressed: the international allocation of resources connected with knowledge carriers. A consensus has never been reached regarding the assumptions on which human capital model calculations should be based, in spite of tireless efforts of definition and standardization of categories (CNUCED/UNCTAD, 1984).

\section{NETWORKS IN KNOWLEDGE-INTENSIVE ACTIVITIES}

The human capital, as well as the traditional brain drain approach, assumes a strong autonomy of economic agents. Every human being is a single unit of human capital, susceptible of moving according to market signals. This initial scheme has undergone many refinements based on market imperfections, information bias or state intervention, etc. However, the basic assumption remains: ultimately, supply and demand determine the flows of skills in the international highly skilled labour market, skills being individually-based properties bounded by human bodies. Recent findings in the social studies of science and technology, as well as in the sociology and economics of labour, clearly challenge this basic assumption and hence the entire relevance of the model. They indeed show the relational dimension of skills, which is inherent to their development as well as to their application. This has a strong impact on the way in which their mobility may be conceived.

The institutionalist school in the sociology of science has shown that the creation, diffusion and utilization of knowledge were very much connected with community behaviour and regulation (Merton, 1973). Extensive evidence has taken this point even further by showing that the very contents of science and technology (natural laws and technical artefacts) were shaped by socio-cognitive groups, therefore conditioned by their common daily practices and tacit knowledge, and were created through local enculturation and action-related experience (Collins, 1974; Latour, 1985). Beyond the doors of research laboratories, innovation studies have increasingly emphasized the importance of collective learning in 
successful firms. Innovation processes, industrial development or, more generally, productive undertakings, are incremental and locally based, requiring dynamic though coordinated interaction among interdependent actors (Freeman, 1990). In these approaches, the concept of networks has obviously received much favour, describing and demonstrating how these socialization processes were at work. Furthermore, the importance of time and its irreversibility, and the path dependency of socio-economic processes involving knowledge creation and utilization, have been underscored (Boyer et al., 1991).

A recent experiment has tried to identify the social and relational components of skills and to measure them separately. This experiment (empirically and analytically) distinguishes between human capital (in terms of broad-based qualifications) and social capital (measured in terms of social networks) in order to determine the respective influence of both on the performance and the productivity of a firm's highly skilled personnel. Its conclusion shows that the first is a less important component than the second in the firm's achievement (Greeve et al., 1999), confirming the increasing evidence provided by management studies on the importance of the context in the determination of skills.

In non-experimental conditions in actual situations, one cannot separate the individual's value from its contextual expression. Skills cannot be understood without their social definition, construction and integration (Mounier, 2001: introduction). New attempts to set up internationally comparative data on the mobility of HRST (Human Resources in Science and Technology) take this complexity of definition into account. These attempts acknowledge the fact that the exercise goes far beyond the technical standardization of instruments used by diverse administrations, and that definitions of skills are at stake and are thus conceptual issues. In particular, the ISCO (International Standard Classification of Occupations) used in conjunction with the ISCED (International Standard Classification of Education), shows the relational dimensions incorporated in the definitions of HRST categories (Auriol, 2001, Appendix 1).

By emphasizing relational and network logics, the above-mentioned recent approaches break with conventional explanations of human capital. These approaches indeed present individuals as being involved in knowledge-intensive activities, deeply rooted in their networks, with their own skills being historically and physically contextualized. This has far reaching consequences for the concept of mobility where highly skilled people are not moving in a vacuum between supply and demand. They are actors whose movements, constructed through and resulting from collective actions, can be traced and described accurately instead of being left to external and elusive macro-determinations. This is not a volatile population of separate units in a fluid environment but rather a set of connective entities that are always evolving through networks, along sticky branches. This is a paradigmatic shift between a substantialist and a connectionist understanding of highly skilled mobility. 
However, the networks referred to here are slightly different from human social networks. In knowledge-intensive activities, human embedded knowledge is only a part of the process involving other entities such as equipment, norms, organizations, etc. These networks are thus often referred to as socio-technical or techno-economic networks (Callon, 1991). They link heterogeneous entities - actors and intermediaries - through which action develops. The actor himher-itself is a composite entity, a network made of what he-she-it can mobilize in action and which makes sense only in relation to other entities within the network. This is why it is often referred to as an actor-network (Murdoch, 1995). We suggest that this expanded network approach be seen as a theoretical framework to describe and explain the new evidence presented in the following paragraphs. The vision put forward by this evidence and these concepts unveils an original assessment and an interpretation of recent events in highly skilled migration.

\section{EXPLORINGEXPATRIATE KNOWLEDGENETWORKS}

Qualitative information about highly skilled expatriates used to be very difficult to gather because of the expatriates' dispersion and mixing within populations in host countries. It was almost impossible to identify individuals and groups of highly skilled persons of foreign origin, and to locate them in significant numbers, across different sectors, occupations and countries. The situation has changed since the beginning of the 1990s, when "expatriate knowledge networks" (Brown, 2000) emerged, providing the opportunity of gathering substantial information about their members.

The rise of highly skilled diaspora networks is in itself significant: 41 appeared between the late ' 80 s and the end of the ' 90 s, linking groups of expatriate intellectuals to their countries of origin (36 - mainly developing - countries) (Brown, 2000). Their rationale is as follows: the presence of highly skilled expatriates abroad should not be seen as a loss to the country but as an asset that can be mobilized. This view departs from earlier options and thinking in terms of recovering the human capital value of individuals through compensation/taxation measures or their embedded knowledge through repatriation programmes without further development (Meyer et al., 1997). The diaspora option, in summary, is based on this assessment: "the expatriates have settled abroad in excellent conditions, ones that we would never have been able to provide them with and which make it unrealistic to call them back here successfully; however, they may still be interested in their country of origin; let's then try to connect them with it and benefit not only from their individual embedded knowledge but also from the extensive socio-professional networks that they have built abroad and to which they are connected in their daily activity" (COLCIENCIAS, 1997). Such a phenomenon therefore reflects the paradigmatic shift from a substantialist to a connectionist viewpoint. 
The development of expatriate knowledge networks has provided a unique opportunity to investigate these particular populations. The evidence presented here draws mainly on two field studies done over the last decade by the Institute of Research for Development in collaboration with the National University of Colombia and the University of Cape Town, on the networks of two countries, Colombia and South Africa: the Colombian Network of Scientists and Engineers Abroad ("red Caldas") and the South African Network of Skills Abroad ("SANSA") (Charum and Meyer, 1998; Brown, 2000). This information is compared with material provided by other networks as well as with general statistical information gathered through several agencies: UNESCO, OST (Paris-based Observatoire des Sciences et des Techniques), NSF (National Science Foundation, in Washington, DC), etc. In the case studies, many techniques were used to bring information to light. General surveys (paper or electronic) were done in 1995-96 and 1998-99, with a return of 783 long questionnaires on Colombia and 2,078 shorter ones on South Africa. In-depth interviews were conducted with 57 important actors in these networks and three complete life (biographical) histories were traced through repeated interviews. Participant observation was practiced during expatriate association meetings, recruiting "head hunting" companies and electronic forums, and massive administrative information was also gathered, both in the countries of origin as well as in the numerous host countries where networks members had settled. Findings on diaspora members rather than the networks as such are presented here.

\section{SOMERESEARCHRESULTS}

The abundant information gathered shows the interrelation between the migration and qualification process. In one's life, moving is often connected with the development of skills and to specific integration into a labour situation. In Colombia, for instance, three out of four persons initially left to pursue their studies, as opposed to 10 per cent who left for professional reasons, a result which coincides with NSF data showing that only one-third of $\mathrm{PhD}$ holders of foreign origin in the US earned their degrees outside the US. The majority of individuals seem to earn their degrees in the host country rather than in the country of origin. It is while they study abroad that they learn about job possibilities and the conditions under which they may access them. It is also during this time that they cognitively prepare themselves for these particular jobs and become acquainted with their future colleagues. There is continuity between the acquisition of an advanced degree and knowledge, and the exercise of a professional career, that is directly or indirectly related to this education. The network that makes an individual suitable for a job is slowly established with a mutual adaptation of actors and intermediaries.

The majority of Colombian expatriates left with an undergraduate degree (bachelor) intending to earn a master's (73 per cent versus 27 per cent) or 
doctorate (93 per cent versus 7 per cent) abroad rather than in the country of origin. If the absence of doctoral programmes at home explains the number of individuals seeking these degrees abroad, this cannot be the reason for the master's degree. Indeed, most disciplines and career training courses are available to this level in Colombia. The fact that most expatriates left before having exhausted the possibilities at home indicates that their departure is not simply due to practical limitations, which invites us to look for other reasons. Interviews, particularly biographical interviews, reveal that persons often made a gradual decision to move abroad while they were still undergraduates. They explain their choice as being based on limited opportunities for development in their field at home, varying from architecture and computer science to microbiology. During their studies, they realized that references, standards, projects, innovations, etc. all came from abroad. They often saw the situation in the country of origin as failing to provide them with the best conditions for self-achievement if they wanted to perform in their specific field. In other words, studies showed both the scope of these disciplines and the extent to which they were limited at home compared with the situation abroad. Access to short and limited networks provided by institutions at home gave these individuals incentives as well as initial means to continue with the longer, complete networks abroad, as a natural prolongation.

The results for South Africa are slightly different: many people leave when they are older and more qualified. This comes as no surprise since the academic system is much more complete and is connected with a more abundant research and industrial establishment. Therefore, in many instances, techno-economic networks are in place and are complete, which also explains a much lower rate of expatriation than for Colombia and the average developing country ( 7 to 10 times less). It is easier, however, to move from South Africa than from many other countries without having to forge skills abroad. Similarities of the educational, occupational and cultural (especially linguistic) systems between this country and the rest of the Commonwealth prepare the way for an expanded employability of persons and the transportability of their skills. This is why more than 75 per cent of highly skilled emigrants go to the UK, US, Canada, Australia and New Zealand. Socio-technical as well as personal networks have long been established, and agreements between firms and universities maintain these via numerous contacts.

There is a commonplace statement in traditional brain drain studies that migration acts as a selective process, selecting the "best and the brightest" from among students and professionals, to be accepted abroad. Retrospective evidence collected from individuals of the diaspora does not confirm this assertion. The qualification level is indeed much higher among expatriates. The number of PhDs in the South African Network of Skills Abroad is, for instance, twice as high as in the graduate population at home. But a more accurate observation reveals that the level was no different at the moment of departure, and those who left were 
not necessarily granted more credits than their fellow colleagues or students at the time. Instead of supposedly superior abilities developed prior to migration, expatriates are driven to uncommon performance because of the migration process as a vital experience, the personal involvement that it requires and the necessity to overcome adverse conditions (compared with those operating in their traditional settings) in competitive environments.

Once established in a foreign country, expatriate professionals are very satisfied with their job situations. They do not think that they are well paid and place greater value on other elements, for instance, relational aspects. Indeed, the main advantages for the majority of Colombian expatriates lie in their opportunity of making international contact with colleagues, the availability of technical or support staff and the access to equipment. Conversely, a high percentage of these expatriates do not see their work today as providing them with any opportunity in the country of origin. In fact, for South African expatriates, only a minority (37 per cent) have professional contacts in the country, while 54 percent have maintained family or personal contact. Links with the country of origin is therefore less professionally orientated and more personal, while professional connections are more evident in the host country.

Diaspora members demonstrate a high stability factor and a commitment to the host country as well as to their home country. Most diaspora members have settled in the country to which they initially migrated when they left the country of origin (Meyer et al., 2001). Far from being wandering intellectuals or business nomads, they are, locally, deeply rooted professionals, even when and if they maintain strong emotional links with the country of origin. Their stability stems from the fact that these highly skilled expatriates are usually in senior, executive positions. For example, the ratio of junior to senior positions in the SANSA network is 1 to 4 , even though the average age remains low. The numerous contacts, be they social, institutional, technical, cognitive or affective, or else implied by these professional involvements, make for a certain stability. Short-term moves are not excluded from such a scheme, but absolute volatility is clearly unrealistic.

Highly skilled expatriates do not have strong links with fellow nationals in host countries. They know only a few, do not often go to national ceremonies, do not subscribe to national newspapers and generally do not register with associations (NGOs) specific to their home country. However, they frequently go back and visit the country (once every two years on average) about which they are curious. But the ties they maintain with it are personal and individual. Ethnic or native bonds are very loose and have no determination over the rest of life. However, when called to participate in a national support scheme, like diaspora knowledge networks, they may react positively and become unexpectedly involved. This kind of network has thus become a social project, a quasiinstitutional form of community generation instead of its by-product. 
Interviewees often mention the difficulties they experience when adjusting to their country of origin. They say that they are today very different to what they used to be before leaving. Looking retrospectively at their career, they say that they would never have imagined doing what they did. When asked about their professional prospects at home, they mentioned that there were good jobs in terms of living conditions and status, but that these jobs were uninteresting and quite different from their current professional situation abroad. For those who attempted to return, the unreliability of colleagues and the weakness of infrastructure have often been huge problems. They felt that conditions were such that their skills and knowledge could not be applied properly. Gaps and discontinuity in the home country's networks have thus often made the outcome of their undertakings unpredictable, sometimes - even frequently, in the cases documented about Colombia - leading to a decision to re-emigrate to the host country. At the opposite, countries having built up a techno-industrial web (like Asian NICs) have witnessed numerous successful returns (Choi, 1995).

The way in which people migrate varies according to their occupation. Evidence shows that in all cases, many links are necessary to build bridges. But these links may differ widely. Researchers, especially from academic sectors, still tend to be more prone towards migration and they migrate through their own ad hoc networks (Meyer et al., 2001). Their departure has generally been prepared long in advance, with contacts established through colleagues, shared projects and knowledge areas, linguistic training, institutional programmes of exchange, etc. They demonstrate a strong desire for mobility as a way to expand their professional opportunities, with little consideration for $\mathrm{CV}$ improvement or career advantage in terms of qualifications, income or status accumulation. Moving is rather a strategic decision: staying in a dynamic and stimulating environment, and creating further contacts and opportunities.

Engineers and information technologists move through more institutionalized channels. They often migrate after they establish contacts with migration services offered by foreign embassies, private migration consultants in the home country, recruitment or head hunting companies or professional association announcements (through websites or specialized journals), etc. These organizational intermediaries are actively putting potential employers into contact with employees at a global level. Evidence shows that these intermediaries do create incentives to move, through all kinds of socio-technical devices, for people who, in many instances, did not express a prior intention to leave.

\section{THE FINDINGS AND SOME OF THEIR CONSEQUENCES}

The evidence underscores the contextual and relational nature of skills and especially of their mobility. One can clearly see that individuals' skills are dependent on the networks that mobilize and activate them. To the actor, these 
networks may be (partly) external or internal. Most of the time, the individual has been professionally shaped abroad, and networks are thus internalized. The contents of her/his skills are indeed tied to the social, technical and economic environments in which he/she has been and with which he/she is still associated. And the position that he/she holds reflects or translates all these earlier and present connections into effective abilities. The actor is thus an actor-network, a black box in which all the components of her/his "socio-skills" are encapsulated. If the network were to change, so would the actor. Which is what happens in failed repatriation attempts, when local networks back home cannot substitute for those prevailing in the host country: the skill is unable to express itself, deprived of all its relational attributes and its usual interfaces.

Measuring the universal value of this actor-network is simply impossible since there is no commensurability between situations in which related data might be captured, before and after migration. The active professional in the host country is different to the student who left the home country years before. To conflate their earlier situation and the present one, and to then deduce a common value, completely offsets the stochastic and irreversible process of life. Obviously, for the same reasons, it is also impossible to speculate on what this value could have been, had the course of personal history been different, with a destiny limited to the borders of the home country. Indeed, this socio-cognitive value would have been determined by the networks built and integrated by the actor in the course of action.

In the minority of cases, when the active professional has undergone complete education and training in the country of origin, and when his/her socio-skills are mobilized afterwards by a new country, networks are external to the actor but are equally determinant in the mobility of this individual. For example, for a computer technologist to move from Johannesburg to Sydney, several intermediaries have to be activated so that both the South African labour market "supply side" specifics are made compatible with the Australian "demand side" specifics. Specialized agents at every stage will provide information about procedures, check correspondence with immigration rules and quotas, ensure the local employability of the person and the transportability of his/her qualifications, estimate related incomes, negotiate with administrative officers, prospect potential employers, provide material guarantees, facilitate travel arrangements, provide access to lodgings and other practical matters, and so on.

The recent proliferation of professional international intermediaries of this kind confirms the fact that globalization of the highly skilled labour market does not occur without massive network investments. In exceptional cases, individuals move quickly from one place to another on their own, and establish immediate contact with a potential employer, through the Internet, for example. This unique situation corresponds to a situation where the networks determining the situation in the home country are very similar and compatible with those set up in the 
prospective host country. Even in these cases, evidence shows that such an adequacy proceeds from a prior, unplanned convergence of elements and contingencies, which, in network terminology, means an alignment (Callon, 1991).

Are networks simple instruments through which market transactions are channelled? Are they the necessary expression at the micro- and meso- levels of the relationship between sovereign macro-entities, supply and demand, determining what the flows should be? Evidence reveals another explanation. The very content of supply and demand is shaped by the networks, by their actors and intermediaries. In fact, there is a co-evolution of supply and demand, and networks through which the adjustments occur. As shown above, the supply of highly skilled manpower is hardly self-declared: it is the result of very active "demand carriers". Closer scrutiny of this demand side reveals that it is not less socially constructed than the supply side, although casual evidence, collected from the diasporas, is more piecemeal.

Most recent debate regarding the urgent need of highly industrialized countries for skills has revolved, in fact, around developments in the information technology industry. According to those in this sector as well as to official migration policy agents, the profiles of information specialists under consideration in this industry did not require as much long-term university training as they did technical knowledge, which, in many cases, could have been gained with professional experience and two years practice. The German case of the "green card programme", for instance, shows that the time required to implement an immigration programme of this kind, between the demand identification period emanating from firms (1999, as a result of prior and mid-1990s major disinvestments in computer training) and the time when the corresponding measures were taken at full speed (mid-2001) is approximately equivalent. One thus understands why trade unions may question the skills immigration policy of the OECD countries (TUAC, Trade Union Advisory Committee to the OECD, intervention, 11 June 2001). Its response to demand, pull factors do not proceed from unproblematic assumptions, as the choice to turn towards migration rather than training is not free of strategic anticipation.

Slowdown of the information industry in the US since the end of 2000 and the subsequent lay-off of hundreds of computer specialists also reveal that the sector's demand was in many instances anticipatory and, as such, quite inflated. This is also a tangible phenomenon in South Africa where firms' surveys on migration issues and the shortage of skills clearly show that there is more a fear of an upcoming deficit of skilled staff than actual immediate widespread deficiencies (Rogerson and Rogerson, 2000). In other words, the representation of demand from firms expressing needs or concerns, does not constitute a completely stable or reliable picture. But the networks connecting these actors - firms with nation states policies and with recruiting agents as well as potential 
employees at the other end of the chain - translate this into an effective demand. Both supply and demand may thus be seen as a result of networks processes instead of objective, autonomous and original determinants of migration flows.

The network approach presented above invites one to reassess the current situation of highly skilled migration (Meyer et al., 2001). Far from emotional accounts of a global volatility of highly skilled personnel with driving forces far beyond actors' control, it reasserts the role of human agency and policy-making, since the situation has never been out of their (collective) hands. In fact, it is within this operational scenario that the connectionist approach is really making a difference with the human capital-based approach. The old paradigm is still active and new, and sophisticated models have thus been produced within this framework. However, thinking in terms of policy options to monitor and manage highly skilled mobility has definitely changed, and traditional brain drain/human capital-based approaches (restriction, repatriation, compensation) are losing ground, as revealed by recent international meetings and initiatives (ECA/ IDRC/IOM, 2000; OCDE, 2001; ILO/DFID, 2001: refer to relevant items in References).

Highly skilled emigration no longer appears as exclusively bad for developing countries. For these countries, some good may come out of this expatriation in terms of increasing access to external resources. Retention of nationals through restrictive measures is thus no longer a definite objective. Repatriation of foreign trained professionals without overall development no longer appears as a solution, and emphasis is placed on science and technology as well as educational policies that could provide incentives and conditions for effective returns. Compensation through the taxation of highly skilled emigrants according to their debatable human capital value is no longer on the agenda. Instead, the very definition of skills is questioned and addressed.

It is clear that relational assumptions have at least informally made their way through these visions. They are even explicitly mentioned in several instances with emphasis placed on "partnership with the diaspora" (ECA/IDRC/IOM, 2000: iii), "scientific diaspora and immigrant entrepreneur networks" (Guellec and Cervantes in OECD, 2001:24), "make recruitment agencies and employers accountable" and "diaspora options" (Lowell and Findlay, 2001; in ILO/DFID, section 6).

The perceptible evolution of policy design has to do with a growing literature that is questioning the way in which the migration of highly skilled workers has been approached, and promoting a vision based rather on circulation than on unilateral flows. Traditional concepts are discussed and challenged, the brain drain in particular (Gaillard and Gaillard, 1997; Johnson and Regets, 1998). New evidence, especially from Asian high tech workers in North America, points to new forms of mobility-related developments (Choi, 1995; Saxenian, 2000). New 
information and communication technologies open unexpected possibilities for scientific diasporas' activities (Brown, 2000; Teferra, 2000). All these approaches refer implicitly or explicitly to networks as the forms through which this circulatory vision is taking shape. The detailed description of highly skilled networks of this type certainly explains how these processes occur. It is the heuristics of this new vision.

\section{CONCLUSION}

An expanded version of the network approach to the migration of highly skilled individuals opens interesting perspectives. It brings new descriptive and conceptual tools to the study of this particular type of migration through a focus on actors and intermediaries in a dynamic construction. This fits in with changes of perception as well as situation with regard to highly skilled migration.

The new expatriate knowledge networks, as spontaneous initiatives of a brain gain strategy through the diaspora option, are unique examples for migration scholars. It is important to learn and understand more about these in order to facilitate their development. Such knowledge networks may be a form of the future; they are in no way a simple and miracle solution.

\section{REFERENCES}

Auriol, L.

2001 "Human resources in science and technology: measurement issues with special regard to international mobility", in International Mobility of Highly Skilled Workers: from Statistical Analysis to the Formulation of Policies, OECD Seminar, June 2001, Paris, (proceedings forthcoming).

Banerjee, B.

1983 "Social networks in the migration process: empirical evidence on chain

Becker, G. migration in India", Journal of Developing Areas, 17(2): 185-196.

1964 Human Capital, Chicago University Press, Chicago.

Boyd, M.

1989 "Family and personal networks in international migration: recent development and new agendas", International Migration Review, 23(3): 638-670.

Boyer, R., B. Chavance, and O. Godard

1991 Les figures de l'irréversibilité en économie, Editions EHESS, Paris.

Brown, $\mathrm{M}$.

2000 "Using intellectual diaspora to reverse the brain drain: some useful examples", in Brain Drain and Capacity Building in Africa, ECA/IDRC/IOM (United Nations Economic Commission for Africa, International Development Research Centre, International Organization for Migration): 90-106. 
Callon, M.

1991 "Techno-economic networks and irreversibility"?, in J. Law (Ed.), A Sociology of Monsters: Essays on Power, Technology and Domination, Routledge, London: 132-161.

Carrington, W., and E. Detragiache

1998 "How big is the brain drain?", IMF working paper, International Monetary Fund, Washington, DC.

Charum, J., and J-B. Meyer (Eds)

1998 Hacer ciencia en un mundo globalizado: la diaspora cientifica colombiana en perspectiva, Tercer Mundo Editores - Universidad Nacional de Colombia, COLCIENCIAS, Bogota.

Choi, $\mathrm{H}$.

1995 An International Scientific Community; Asian Scholars in the United States, Praeger, London.

Choldin, $\mathrm{H}$.

1973 "Kinship networks in the migration process", International Migration Review, 7(2): 163-175.

CNUCED(UNCTAD)

1984 Etablissement d'un ensemble de définitions, de principes, de lignes directrices et de régles acceptées au niveau international en ce qui concerne tous les aspects du transfert inverse de technologie, Principaux éléments d'un ensemble convenu internationalement de principes, de définitions et de normes sur le transfert inverse de technologie, United Nations Conference on Trade and Development, TD/B/AC.35/7, Geneva.

\section{COLCIENCIAS}

1997 Descripción de la red Caldas/Description of the Colombian "Caldas" Network of Scientists and Engineers Abroad, COLCIENCIAS, Bogota, mimeo.

Collins, $\mathrm{H}$.

1974 "The TEA set: tacit knowledge and scientific networks", Science Studies, 4.

Fawcett, J.

1989 "Networks, linkages and migration systems", International Migration Review, 23(3): 638-670.

Freeman, C.

1990 "Networks of innovators: a synthesis of research issues", Séminaire International sur les Réseaux d'Innovateurs, 1990, Montreal.

Gaillard, A.M., and J. Gaillard

1998 International Migration of The Highly Qualified: A Bibliographic and Conceptual Itinerary, Centre for Migration Studies, New York: 142.

Gaillard,. J., and A.M. Gaillard

1997 "The International Mobility of Brains: Exodus or Circulation?", Science, Technology and Society, 2(2): 195-228.

Gelderblom, D.

1999 "Do migrants networks function to diffuse the advantages of migration or are they mechanisms of exclusion? Social differentiation and the migration literature", paper presented at South African Sociological Association conference, July 1999, Saldhana Bay: 1-17. 
Granovetter, M.

1974 Getting a Job: A Study of Contacts and Careers, Harvard University Press, Cambridge, Massachusetts.

Greeve, A., M. Benassi, and J. Harkola

1999 "Comparing the influence of human and social capital on performance", paper presented at SUNBELT XIX, INSNA Conference, February 1999, Charleston, South Carolina.

Guellec, D., and M. Cervantes

2001 "The impact on innovation and economic performance of the international mobility of highly skilled workers", in International Mobility of Highly Skilled Workers: from Statistical Analysis to the Formulation of Policies,

Gunatilleke, G. OECD Seminar, June 2001, Paris, (proceedings forthcoming).

1998 "The role of networks and community structures in international migration from Sri Lanka", in R. Appleyard (Ed.), Emigration Dynamics in Developing Countries, volume II, South Asia, Ashgate Publishers, Aldershot.

Gurak, D., and F. Caces

1992 "Migration networks and the shaping of migration systems", in M. Kritz, L.L. Lim, and H. Zlotnick (Eds), International Migration Systems: A Global Approach, Clarendon, Oxford: 150-176.

Hammar, T., G. Broschmann, K. Tamas, and T. Faist (Eds)

1997 International Migration, Immobility and Development: Multi-Disciplinary Perspectives, Berg, Oxford, New York.

Haque, N.U., and S. Kim

1994 "Human capital flight: impact of migration on income and growth", IMF working paper, International Monetary Fund, Washington, DC.

Johnson, J., and M. Regets

1998 International Mobility of Scientists and Engineers to the United States: Brain Drain or Brain Circulation?, NSF-Issue Brief 98-316, National Science Foundation, Washington, DC.

Kuhn, T.

1962 The Structure of Scientific Revolutions, Chicago University Press, Chicago.

Latour, B.

1987 Science in Action, How to Follow Scientists and Engineers Through

Society, Open University Press, Cambridge, Massachusetts.

Lowell, L., and A. Findlay

2001 "Migration of highly skilled persons from developing countries, impact and policy responses, synthesis report", in Skilled Labour Migration ("the Brain Drain”) from Developing Countries; Analysis of Impact and Policy Issues, International Labour Office, Geneva (forthcoming).

Merton, R.

1973 The Sociology of Science, Chicago University Press, Chicago.

Meyer, J-B., and J. Charum

1995 "La fuite des cerveaux est-elle épuisée? Paradigme perdu et nouvelles perspectives", Cahiers des Sciences Humaines, 31(4): 1003-1017, Spanish version "Se agotó la fuga de cerebros? Paradigma perdido y nuevas perspectivas", Integración Ciencia y Tecnología, 1(1) (Diciembre 1994). 
Meyer, J-B., D. Kaplan, and J. Charum

2001 "Scientific nomadism and the new geopolitics of knowledge", International Social Sciences Journal/Revue Internationale des Sciences Sociales, 168.

Montgomery, J.

1991 "Social networks and labor market outcomes: toward an economic analysis", American Economic Review, 81(5): 1408-1418.

Mounier, A.

2001 "The three logics of skills", ACCIRT working paper no. 66, University of Mullan, B.P. Sydney, Sydney.

1989 "The impact of social networks on the occupational status of migrants", International Migration, 27(1): 69-86.

Murdoch, J.

1995 "Actor-networks and the evolution of economic form: combining description and explanation in theories of regulation, flexible specialization and networks", Environment and Planning A, 27: 731-757.

Nogle, J.M.

1994 "The systems approach to international migration: an application of network analysis methods", International Migration, 32(2): 329-342.

Pohjola, A.

1991 "Social networks - help or hindrance to the migrant?", International Migration, 29(3): 435-444.

Rogerson C.M., and J.M. Rogerson

2000 "Dealing in scarce skills: employer responses to the brain drain in South Africa", Africa Insight, 30(2): 31-40.

Saxenian, A.L.

2000 "Silicon Valley's New Immigrant Enterpreneurs", working paper no. 15, Center for Comparative Immigration Studies, University of California, Santa Cruz: 30.

Shah, N., and I. Menon

1999 "Chain migration through the social network: experience of labour migrants Teferra, D. in Kuwait," International Migration, 37(2): 361-382.

2000 "Revisiting the doctrine of human capital mobility in the information age", in Brain Drain and Capacity Building in Africa, ECA/IDRC/IOM (United Nations Economic Commission for Africa, International Development Research Centre, International Organization for Migration): 64-79.

Wong, S., and J. Salaaf

1998 "Network capital: emigration from Hong Kong", British Journal of Sociology, 49(3): 258-274. 


\section{L'EXODE DES CERVEAUX SUPPLANTE PAR L'APPROCHE "RESEAU": LES LEÇONS DE LA DIASPORA}

Au cours des deux dernières décennies, la constitution de réseaux a donné lieu à bon nombre de développements théoriques et empiriques dans le cadre des études consacrées d'une part à la migration internationale et d'autre part aux innovations technologiques. Il est cependant surprenant de constater que cette approche n'a guère été utilisée pour étudier le résultat de la rencontre de ces deux phénomènes, à savoir la mobilité de la main-d'œuvre hautement qualifiée et des experts.

Cet article s'appuie sur les témoignages récents apportés par des études de cas consacrées aux réseaux de la diaspora intellectuelle, en s'efforçant de combler cette lacune et d'explorer la question. Ces réseaux d'expatriés hautement qualifiés transforment l'exode des cerveaux en une approche d'acquisition de cerveaux par l'établissement de liens entre les membres de la diaspora et leurs pays d'origine. Ces personnes et ces groupes apportent en outre des éléments d'information originaux qui remettent en question les thèses conventionnelles relatives au capital humain.

L'auteur de l'article constate que les réseaux dont il est question font entrevoir des perspectives intéressantes sur le plan de la compréhension et de la gestion de la circulation actuelle de connaissances spécialisées dans le monde. L'approche "réseau" qui fait l' objet de cet article prend en considération à la fois des données relatives aux flux migratoires et des résultats d'études consacrées aux innovations technologiques. Elle laisse aussi entrevoir une dimension d'ellemême élargie aux acteurs et aux intermédiaires, dans laquelle les accointances traditionnelles ne constituent qu' une partie seulement d'une dynamique associative plus systématique actuellement à l'œuvre.

\section{PERSPECTIVA DEL ESTABLECIMIENTO DE REDES DE CARA A LA FUGA DE CELEBROS: LECCIONES APRENDIDAS DE LA DIÁSPORA}

Durante las últimas dos décadas, las perspectivas de establecimiento de redes han conducido a acontecimientos conceptuales y empíricos en los estudios de migración internacional y también de innovación tecnológica. Ello no obstante, y de manera sorprendente, estas perspectivas no han sido utilizadas para estudiar lo que se encuentra en la intersección de ambos campos, a saber, la movilidad de personas altamente calificadas o de trabajadores competentes.

Este artículo aprovecha recientes pruebas extraídas de estudios por casos sobre las redes de diásporas intelectuales para colmar esta brecha y explorar la 
cuestión. Estas redes de expatriados altamente calificados, recurren a la perspectiva conexionista para vincular a los miembros de la diáspora con sus países de origen y transforman la fuga de cerebros más bien en una ganancia de cerebros. Estas personas y grupos también proveen información original que ponen en tela de juicio las hipótesis convencionales basadas en el capital humano.

Este artículo arguye que las descripciones en términos de redes abren perspectivas interesantes para la comprensión y gestión de la actual circulación mundial de personal calificado. La perspectiva de redes que aquí se considera combina la aportación de la migración con estudios innovadores. Ello sugiere una versión ampliada de la perspectiva de redes, que alude a los protagonistas e intermediarios, para quienes los vínculos parentales tradicionales no son más que parte de una dinámica sistemática y asociativa, que predomina realmente. 